\title{
FACTORS CONTROLLING CORONAVIRUS INFECTIONS AND DISEASE OF THE CENTRAL NERVOUS SYSTEM
}

\section{A Review}

\author{
S. Dales \\ Department of Microbiology and Immunology \\ University of Western Ontario \\ London, Ontario \\ N6A 5C1 \\ Canada
}

\section{INTRODUCTION}

This review summarizes 18 years of investigations in this laboratory on factors controlling the infectious process in cells of the central nervous system (CNS). The model chosen by us which involves rodents challenged with neurotropic murine coronavirus (CV) JHMV, was selected on the presumption that pathogenesis due to viral infections can be a trigger for sequelae culminating in autoimmune disease like that presumed to cause multiple sclerosis (MS) in humans. Our model, based on the initial 1949 reports about initiation of neurologic disease in rats and mice by $\mathrm{JHMV}^{1,2}$ has been refined and amplified upon ${ }^{3}$. More recent evidence, which includes detection of viral RNA and protein in neural cells some albeit circumstantial, has implicated both the rodent and ubiquitous human OC43 or 229E $\mathrm{CVs}$ in CNS pathologies including demyelinative disease $\mathrm{e}^{4,5}$. The key interrelated parameters relevant to the model examined by us which will be considered here include the influence of age and development of the host animal, its immune responses, genetic constitution and variability of the infecting viral agent. For the sake of clarity, realizing that it may be an oversimplification, CNS infections associated primarily with neurons (NEU) are designated as grey matter (GM) disease while those involving glial cells, especially astrocytes (AS) and oligodendrocytes (OL), which cause demyelinative lesions are termed white matter (WM) disease.

Due to the brevity of this review, it was necessary to focus predominantly on data emanating from this laboratory, without intention to minimize the salient contributions of colleagues elsewhere. In most cases, the pertinent reference to studies of others can be found in bibliographies of the articles cited here. 


\section{FACTORS IN THE DISEASE PROCESS}

a) age related resistance: the intracerebral (IC) inoculation of JHMV into neonate rats induces an acute encephalitis due to rapidly and widely disseminated GM involvement. A postnatal interval between 1 week and 3 weeks of age, at the time weaning occurs in rats is a period or "window" of susceptibility involving the WM. This corresponds well with completion of CNS myelination and OL maturation ${ }^{6}$. By contrast, the more gradual, prolonged myelination and maturation in the murine $\mathrm{CNS}$ correlates with an extended period into the lifespan of susceptibility to WM disease induced by $\mathrm{JHMV}^{7}$.

b) immune responses: the unambiguous evidence for the role of cellular immunity in controlling JHMV infections of the rat CNS contrasts with clear cut involvement of humoral immunity. Thus, in athymic nude $(\mathrm{Nu} / \mathrm{Nu})$ rats and mice or following immunosuppression by drugs such as cyclosporin $\mathrm{A}$, the normal age-related resistance is abrogated $\mathrm{d}^{8,9}$ and a productive infection can be elicited in rats at any age post-weaning. However, as a consequence of impaired cellular immunity, the disease produced is predominantly of the GM, associated with extensive NEU involvement which results in an acute, rapidly fatal encephalitis $^{8,9}$. In the case of humoral immunity, localized anti-JHMV immunoglobulin synthesis can be monitored in the cerebrospinal fluid without appearing to influence the progress of WM-associated paralytic disease ${ }^{10}$.

c) genetic constitution of the host: the published information dealing with this complex subject is too voluminous for adequate review here, limiting the selected material to our own studies on rodents. Concerning the rat model, strain differences occur in the "window of susceptibility" interval during which WM disease can be elicited by JHMV. Wistar Furth (WF) rats are genetically deficient in circulating growth hormone. Presumably related to this deficiency is a slower postnatal CNS maturation. Wistar Lewis (WL) rats possess normal levels of growth hormone, earlier onset of WM maturity and easily provoked, vigorous inflammatory cell responses in the CNS. Comparisons on susceptibility to WM disease showed that in WF the paralytic, demyelinative process can be induced by JHMV inoculation ic for significantly longer periods than in WL rats ${ }^{11}$. Genetic analysis by cross-breeding and backcrossing revealed that the heritable phenotype for resistance (R) is controlled by a single gene and that in WF strain this trait segregates as a homozygous recessive rr while in WL rats it occurs in a heterozygous form $R R, R r$ and $r$.

Genetically determined host resistance $v s$ susceptibility to CV can be defined unambiguously in specific strains of mice. Comparison between strain SJL/J which is resistant and CD.1 (or BALB/c) which are sensitive to challenge with neurotropic CVs JHMV or A59 showed by crossbreeding in the $\mathrm{F} 1$ generation that resistance is recessive, i.e., susceptibility is dominant ${ }^{12}$. These data were reflected exactly by correlative results from virus replication in primary cell explants from the CNS of embryonic mice ${ }^{13}$, as illustrated in Table I.

Analysis of JHMV adsorption and expression revealed that arrest of this CV strain in cells of SJL/J mice was most probably due to an arrest in cell-to-cell spread, not to the lack of either receptors or virus-specified expression. It is possible that $\mathrm{SJL} / \mathrm{J}$ cells lack a protease activity which is required to activate the $\mathrm{S}$ fusogenic component of the virus.

d) genetic variability of the virus: once again the variability and complexity of the evidence gathered on this subject precludes inclusion of an authoritative review in this article. To explain virulence, tropism and pathogenesis of CVs, variability among the components, especially of the $\mathrm{S}$ glycoprotein has been invoked, sometimes based on contradictory data (see ${ }^{12}$ for several citations). Our studies have been concerned with neural cell tropism of the closely related viscerotropic $\mathrm{MHV}_{3}$ and neurotropic JHMV CVs. Challenge of primary neural rat cultures enriched for specific cell types demonstrated that $\mathrm{MHV}_{3}$ had preferential tropism for type 1AS (1AS) and JHMV for $\mathrm{OL}^{14}$. JHMV produces WM 
Table I. Comparison of CV replication in glial cultures ${ }^{a}$ from purebred and hybrid mice

\begin{tabular}{lcccc}
\hline \multirow{2}{*}{$\begin{array}{l}\text { Mouse strain from which } \\
\text { cultures originated }\end{array}$} & \multirow{2}{*}{$\begin{array}{c}\text { Time after } \\
\text { inoculation }(\mathrm{h})\end{array}$} & $\mathrm{JHMV}^{\mathrm{c}}$ & $\mathrm{MHV}_{3}{ }^{c}$ & $\mathrm{~A}$ \\
\cline { 3 - 5 } & 12 & $017 \pm 029(3)$ & $590 \pm 114(3)$ & $6 \pm 2(6)$ \\
\hline SJL & 24 & $23 \pm 12(14)$ & $435 \pm 292(14)$ & $13 \pm 05(6)$ \\
& 48 & $48 \pm 20(14)$ & $886 \pm 62(10)$ & $2 \pm 06(3)$ \\
& 72 & $22 \pm 9(12)$ & $475 \pm 119(6)$ & $\mathrm{ND}^{d}$ \\
& & & & \\
CD 1 & 12 & $350 \pm 216(5)$ & $77 \pm 12(4)$ & $\mathrm{ND}$ \\
& 24 & $3260 \pm 2110(13)$ & $778 \pm 30(11)$ & $21,300 \pm 19,600(3)$ \\
& 48 & $9440 \pm 500(9)$ & $3340 \pm 2300(7)$ & $95,800 \pm 2700(3)$ \\
$(\mathrm{CD} \mathrm{1} \times \mathrm{SJL}) \mathrm{F}_{1}$ & & & & \\
& 24 & $961 \pm 34(5)$ & $1120 \pm 730(5)$ & $\mathrm{ND}$ \\
& 48 & $6260 \pm 4320(5)$ & $2400 \pm 2000(5)$ & $\mathrm{ND}$ \\
& 72 & $943 \pm 480(5)^{e}$ & $213 \pm 52(5)^{e}$ & $\mathrm{ND}$ \\
\hline
\end{tabular}

${ }^{a}$ Primarily oligodendrocytes and astrocytes (35)

${ }^{b}$ The values are means with standard deviations The number of cultures tested is shown in parentheses

'MOI, 1 PFU per cell

${ }^{d} \mathrm{ND}$, not determined

${ }^{e}$ Decrease in titers was attributed to rapıd cell kıllıng (from ref 13 )

disease but $\mathrm{MHV}_{3}$ does not evoke any CNS disease symptoms. This mutually exclusive tropism demonstrated with rat neural cells does not occur in murine $1 \mathrm{AS}$ and OL, both of which are infectable by both the viscerotropic and neurotropic agents ${ }^{15}$.

\section{CORRESPONDENCE BETWEEN THE IN-VIVO VS IN-VITRO DISEASE PROCESS}

The IC inoculation of rats with JHMV at intervals post-partum, up to the age of weaning causes either the acute encephalytic GM disease or a progressive demyelinative WM disease with paralysis or paresis, depending on the age at challenge ${ }^{6}$. To determine age and disease related JHMV expression in the CNS presence of viral antigen was monitored by immunocytology and viral RNA by probing with specific cDNA in dot-blot assay. Virus materials were pinpointed within five functional zones of the CNS, defined anatomically in

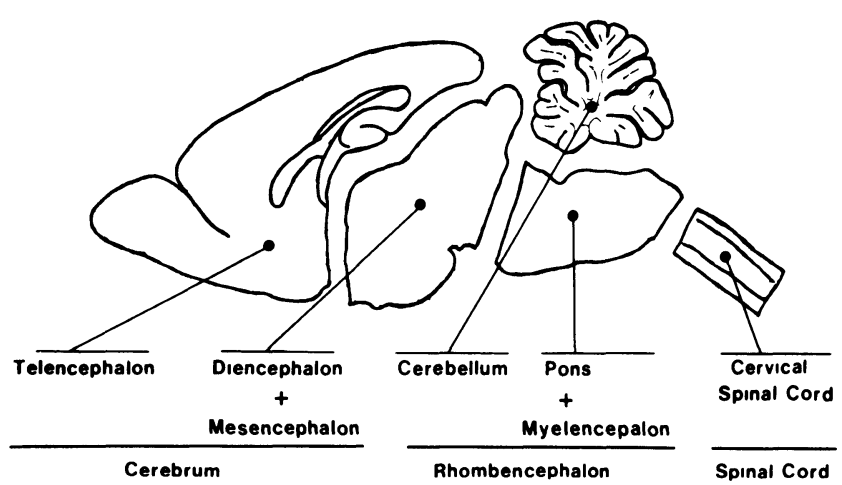

Figure 1 


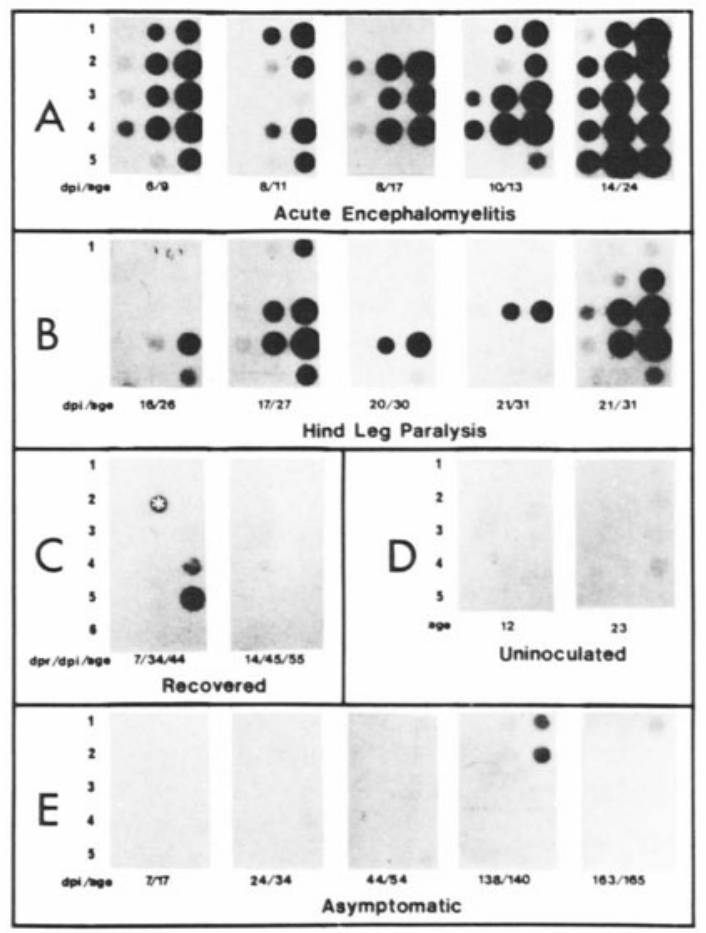

Figure 2. Dot-blot analysis of CNS tissue extracts prepared from samples taken from rats with either (A) acute encephalomyelitis, or (B) hind-leg paralysis, or $(C)$ after recovery from paralysis, and (D) uninoculated controls as well as (E) asymptomatic anımals Each row is composed of RNA extracts blotted at dilutions of $1 / 100,1 / 10$, and $1 / 1$ The numbers of the ord 1 nate represent the tissues sampled as follows 1 . telencephalon, 2 diencephalon/mesencephalon, 3. cerebellum, 4 pons/myelencephalon, 5 cervical spinal cord, 6 lumbar spinal cord, dpr: days post recovery, dp1. days post inoculation *This result is anomalous since other blots in this dilution series were negative (Ref 10 )

Figure 1. It is evident from the dot-blot analysis in Figure 2 that virus can be disseminated rapidly throughout the CNS. In the case of WM disease process, centers of infection are established prior to evidence of any tissue damage associated with the progressive form of demyelinative disease. JHMV specific RNA is detectable in the CNS of rats which have recovered from paralytic disease symptoms and in rats which have remained asymptomatic for 5 months and beyond. This and related studies demonstrated surprisingly the capacity of this neurotropic virus, possessing a plus sense single stranded RNA genome, to remain within the CNS for prolonged periods, perhaps indefinitely in a persistent or latent state, despite absence of any known mechanism for establishing a provirus replication strategy like that used by retroviruses.

We sought to define more precisely the parameters regulating JHMV infections of neural cells in vivo by examining virus-cell interactions under the tighter controlled conditions possible in vitro. For this purpose, explant cultures were established from embryonic or neonatal CNS tissue enriched in NEU originating in the hippocampus or OL lineage precursors from the telencephalon. The virus-cell interactions pertaining to either NEU or OL will now be considered in separate sections.

a) studies on neurons: our data, described in several published articles reveal that NEU involvement is extensive throughout the CNS GM, during acute encephalitis. When the progressive demyelinative, paralytic form of WM disease occur hippocampal and cerebellar neurons contain JHMV RNA and protein ${ }^{16}$, illustrated in Figure 3. Since viral RNA persists for long periods in asymptomatic and recovered rats ${ }^{10}$, we assume that NEU may provide the reservoir for virus persistence.

A specific, close association between JHMV nucleocapsids $(\mathrm{N})$ and bundles of microtubules within neurites was observed in thinly sectioned cultured hippocampal neurons ${ }^{17,18}$. This association is perhaps established because there is protein "mimicry", uncov- 
Figure 3. Coronavirus antigen and RNA in the hippocampus of JHMV-infected rats. (A) Immunohistochemical detection of $\mathrm{N}$ protein in the hippocampus of a JHMV-infected rat. Arrow points to an $\mathrm{N}^{+}$neuron within Ammons's horn. Other $\mathrm{N}^{+}$cells are likely glia. (B) Coronavirus RNA in the hippocampus detected by in situ hybridization using a JHMV-specific $\left[{ }^{35} \mathrm{~S}\right\}$ cDNA probe. Arrows point to two positive neurons. (Ref. 16).

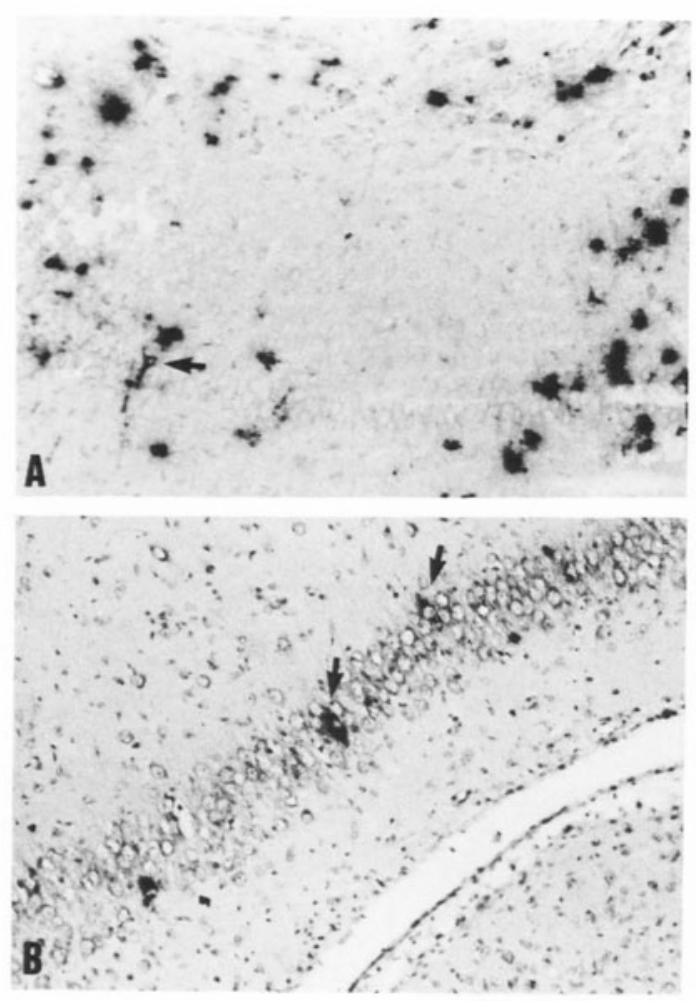

ered by computer sequence matching between $\mathrm{N}$ and the microtubule-binding domain of the microtubule associated protein tau ${ }^{18}$, illustrated in Figure 4. Relatedness of $\mathrm{N}$ to tau is further substantiated by immunological relatedness shown in a companion article ${ }^{19}$. These findings draw attention to: 1) a strategy of a CV for making use of the host's normal function on behalf of the virus. 2) involvement of microtubules in replication, trafficking of virus proteins and assembly of progeny particles ${ }^{18}$.

b) infections of oligodendrocytic lineage cells: glial progenitors explanted from the rat optic nerve have the potential to differentiate into mature OL or $2 \mathrm{~A}$ astrocytes ${ }^{20}$. These progenitors marked as of the O-2A phenotype are programmed in the same "time-clock" required for becoming mature, myelin producing $\mathrm{OL}$ as that which prevails in vivo. Throughout development and maturation phenotypic markers, many present at the cell surface, identify the various stages recognizable by means of specific antibodies, as shown in Figure 5. When such antibodies are applied, it is evident that soon after explantation of tissue from the telencephalon, most OL progenitors are in the mitotically active $\mathrm{A} 2 \mathrm{~B}^{+}$juvenile stage:

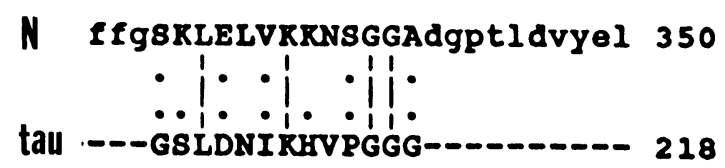

Figure 4. Evidence for amino acid sequence homology between tau and N. Identical residues are linked by vertical lines, related ones by two dots when homology is closer or one dot when it is less close. The tau sequence is the invariant 12-mer of the microtubule binding motif matched with $\mathrm{N}$ sequence from the carboxyl terminus. 

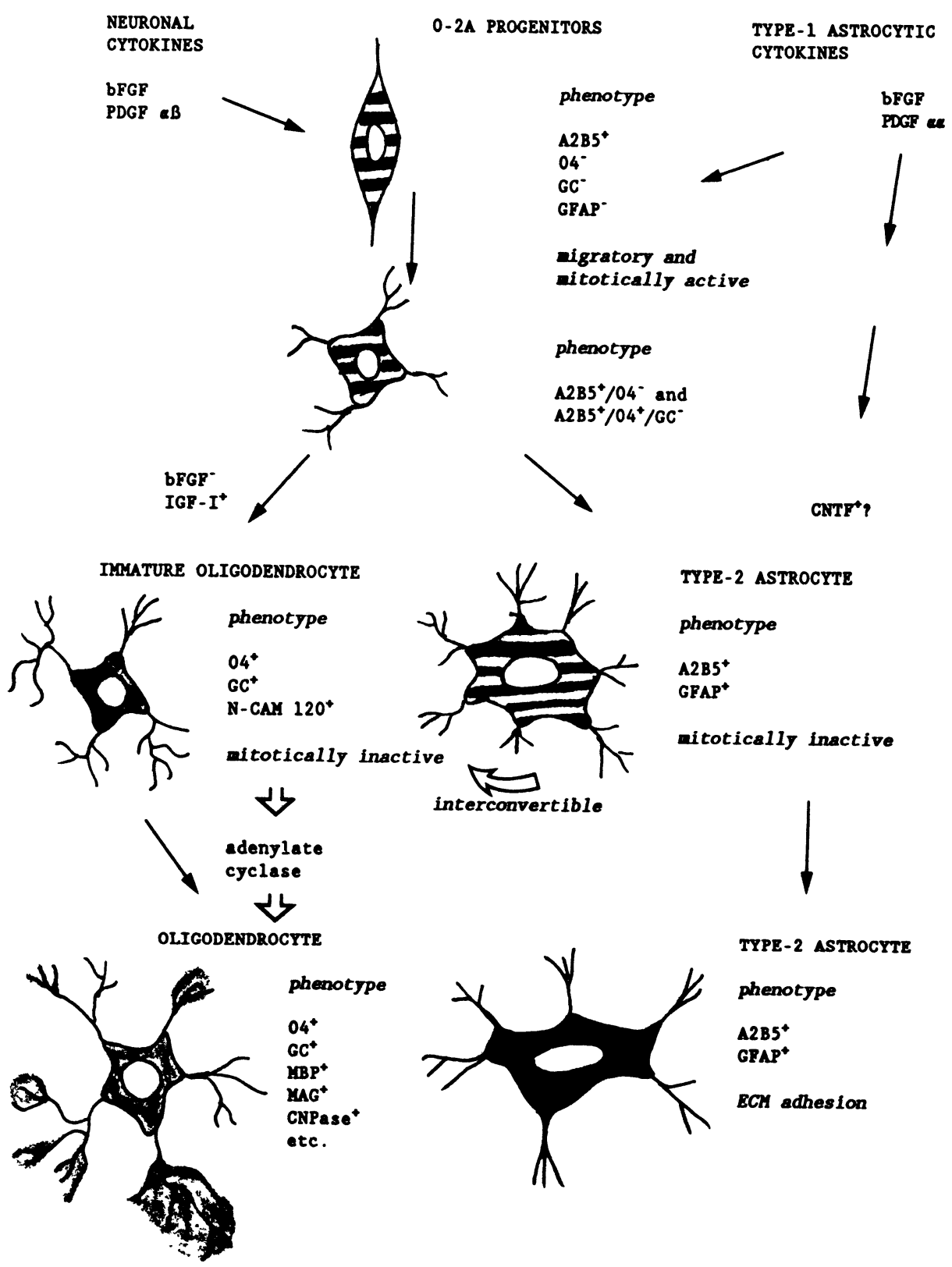

Figure 5. Developmental scheme for oligodendrocytes.

a phase during which they are amenable to mitotic arrest by application of ng amounts of cytokines bFGF and PDGF $\alpha \alpha$. The influence of cytokines is completely reversible. The A2B5+ cells which are refractory to infection by JHMV become susceptible when treated with bFGF and PDGF (Figure 6). Upon removal of the cytokines they regain their resistance ${ }^{17}$.

Later, during terminal stages of development, the mature OL synthesize myelin specific and other constituents, including myelin basic protein (MBP), associated glycoprotein (MAG), galactocerebroside (GC) and 2':3'-cyclic nucleotide-3'-phosphohydrolase (CNPase) (Figure 5). During the terminal stages of differentiation, OL once again became 
Figure 6. Effects of $\mathrm{bFGF}$ and PDGF on the replication of JHMV in enriched O-2A line age cultures $\mathrm{O}-2 \mathrm{~A}$ lineage cells derived from 9 DIV and P9 mixed telencephalic cultures were plated at $25 \times 10^{5}$ cells per $\mathrm{cm}^{2}$ and grown for $48 \mathrm{~h}$ in $\mathrm{O} 1 / \mathrm{T} 3$ alone or $\mathrm{O} 1 / \mathrm{T} 3$ supplemented with bFGF (10 ng/ml), PDGF $(10 \mathrm{ng} / \mathrm{ml})$, or bFGF plus PDGF before inoculation with JHMV at a MOI of 2 Data are the means of titers \pm standard deviations from triplicate cultures and are representative of three independent experıments (Ref 17)

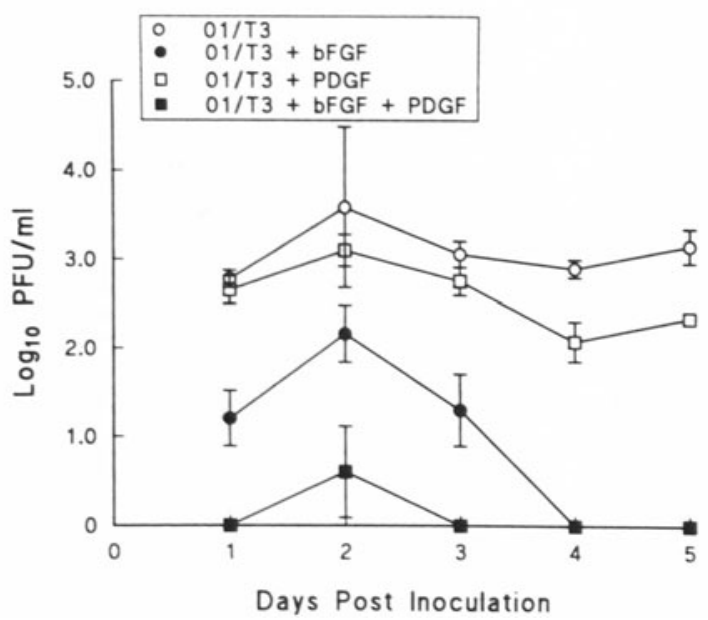

non-infectable by JHMV ${ }^{14}$ Differentiation of OL can be deliberately accelerated by upregulatıng the adenylate cyclase metabolic pathway employing metabolites such as cyclic AMP $^{1421}$ After treatment of purified progenitors with $1 \mathrm{mM}$ dbcAMP for 1 or 2 days the mature OL phenotype is expressed and coincidentally infectability by JHMV ceases The block occurs at a stage after adsorption but before any virus functions are expressed The arrested stage is likely to involve uncoatıng because 1) The $56 \mathrm{kDa}$ protein $\mathrm{N}$ of inoculum virus is rapidly converted to the less phosphorylated $50 \mathrm{kDa}$ form, prior to breakdown to low MW fragments, as shown in Figure 5 2) treatment with dbcAMP after replication has commenced does not suppress JHMV ${ }^{14}$ 3) infection of mature OL can be initiated by

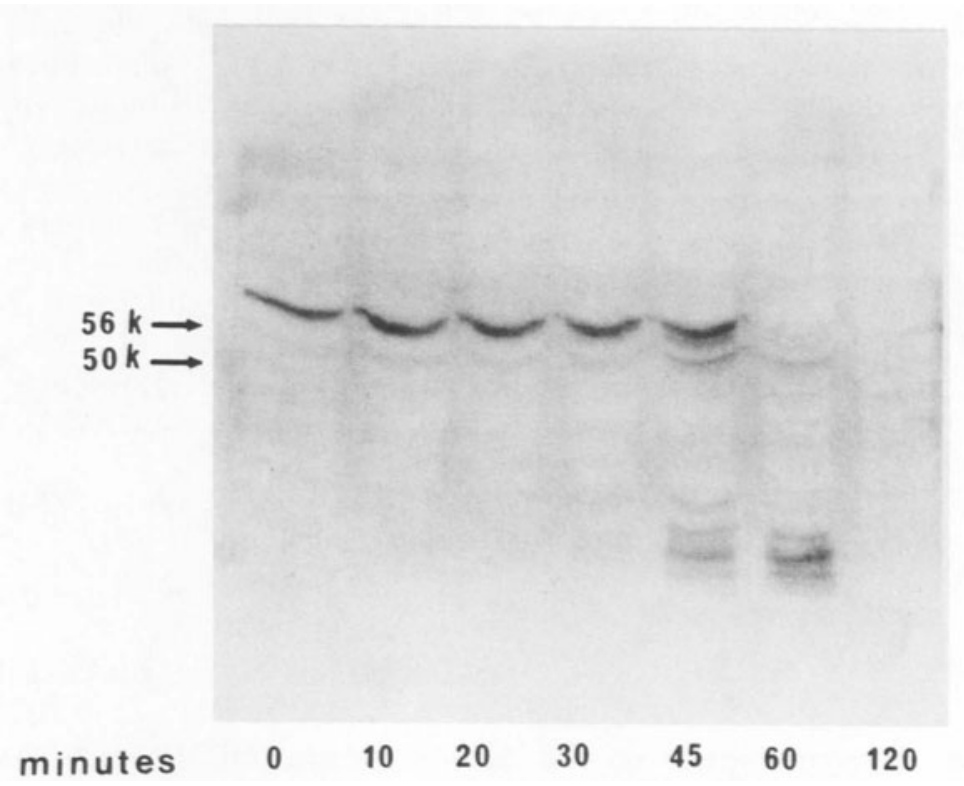

Figure 7. Modulation of N protein during 120 min of JHMV penetration into L-2 cells The antigen is identıfied by ımmunoblottıng employıng monoclonal antı $\mathrm{N}$ antıbody (Mohandas, D, Wilson, $\mathrm{G}$ and Dales, $\mathrm{S}$, unpublished) 

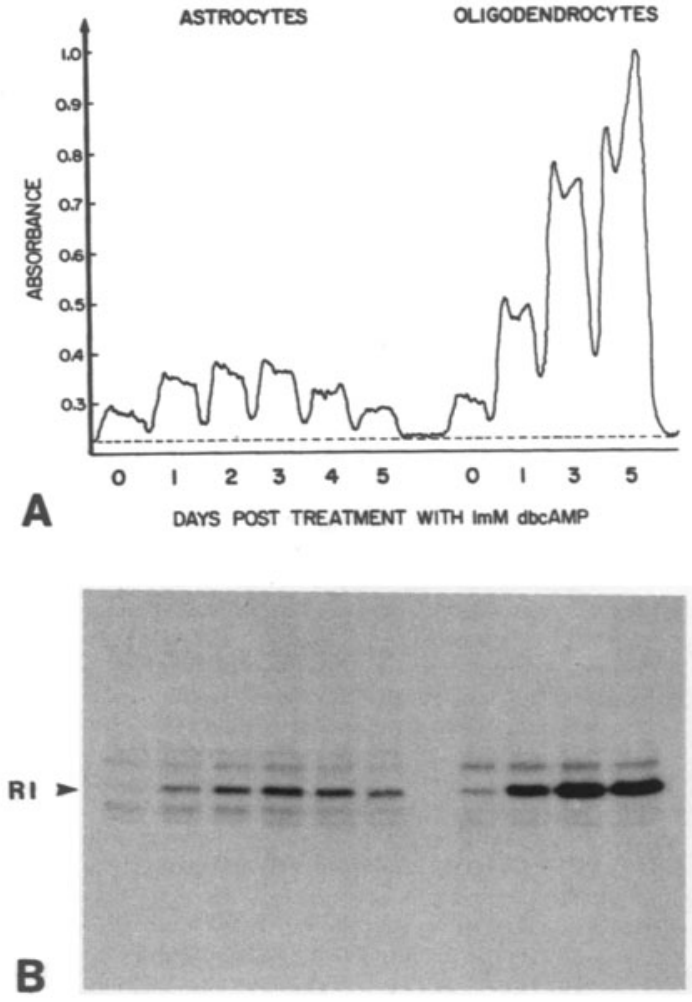

Figure 8. Modulation of RI and RII in primary rat astrocytes and oligodendrocytes during treatment with $1 \mathrm{mM}$ dbcAMP. The concentrations of the regulatory subunits in cytosol $(100,000 \times$ $g$ ) fractions from astrocytes and oligodendrocytes were determined by binding of 8 -azido$\left[{ }^{32} \mathrm{P}\right]$ cAMP, as described in Materials and Methods. A densitometer tracing (A) made from an autoradiogram (B), obtained after 10\% SDSpolyacrylamide gel electrophoresis, enabled a comparison of the time-related changes in the RI regulatory subunit. Absorbance units have been normalized to the band of greatest density (oligodendrocytes, 5 days posttreatment). (Ref. 21)

transfecting with isolated genomic virus RNA ( $\mathrm{se}^{19}$ companion article). From the knowledge that the genome within inoculum virions is coated by the phosphorylated form of $\mathrm{N}^{22}$ we hypothesize that deficiency of uncoating in mature OL might be due to suppression of dephosphorylation of $\mathrm{N}^{21}$. We also predicted that the dephosphorylating activity involved is a phosphoprotein phosphatase (PPPase) acting on $\mathrm{N}$ of penetrating inoculum virus. Evidence was obtained that a type 1 PPPase is associated with host cell endosomes, possesses a highly specific activity against phosphorylated $\mathrm{N}$ as the substrate ${ }^{23}$ and is inhibitable by the regulatory subunit $\mathrm{R}$ of cAMP-dependent protein kinase $\mathrm{I}^{24}$. The upregulation of $\mathrm{R}$ expression in mature $\mathrm{OL}^{21}$, shown in Figure 8, provided a rationale for the existence of a relationship between maturation and JHMV suppression in OL. This idea was supported by our demonstration of virus suppression upon transfection of the RI gene into non-neural L2 cells (see 19 companion article), but an absence of suppression when infectious genomic RNA is used in place of intact virions to initiate JHMV replication.

Experimental evidence obtained on the PPPase from assays in cell-free reactions supports the findings on intact cells ${ }^{24}$ (and unpublished data).

\section{SUMMARY AND CONCLUSIONS ABOUT OLIGODENDROCYTES}

There is a correlation between specificity of tropism of JHMV for O-2A lineage cells from the rat and demyelination of white matter, associated with chronic disease. Susceptibility to infection, which can occur in O-2A cells before terminal differentiation may be influenced by cytokines. During the normal, age-related or rapidly induced maturation/dif- 


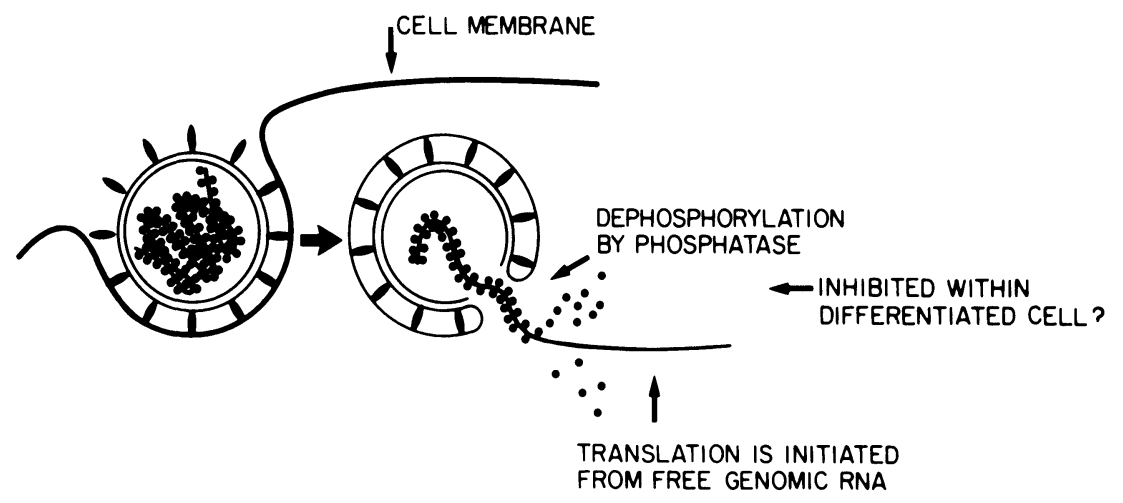

Figure 9. Early cell-vırus interactions

ferentiation of rat oligodendrocytes, suppression of JHMV replication is correlated with upregulation of the subunit R1 of the cAMP-dependent protein kinase Virus inhibition occurs at a stage between penetration and initiation of genome expression Regulation over coronavirus infection of oligodendroglia is strictly controlled by the host cell There is evidence that induction of R1 subunit of protein kinase A influences uncoating, illustrated in Figure 9, by suppression of dephosphorylation during penetration Our former workıng hypothesis, now borne out by recent data predicts that the infection in mature oligodendrocytes is blocked because specific dephosphorylation of the capsid protein $\mathrm{N}$, required for uncoatıng, etc is suppressed

\section{REFERENCES}

1 Baıley, O T, Pappenheımer, A M, Cheever, F S, Daniels, J B A murıne vırus (JHM) causing dissemınated encephalomyelitis with extensive destruction of myelın II Pathology J Exp Med 1949,90 195-231

2 Cheever, F S, Danıels, J B , Pappenheımer, A M, Baıley, O T A murıne virus (JHM) causing dissemınated encephalomyelitis with extensive destruction of myelin I Isolation and biological properties of the virus J Exp Med 1949,90 181-194

3 Werner, L P Pathogenesis of demyelınation induced by a mouse hepatıtıs virus (JHM virus) Arch Neurol 1973,28 298-303

4 Stewart, J N , Mounir, S, Talbot, P J Human coronavirus gene expression in brains of multiple sclerosis patients Virology 1992,191 502-505

5 Murray, R S , Brown, B , Brian, D , Cabırac, G F Detection of coronavirus RNA and antigen in multıple sclerosis brain Ann Neurol 1992,31 525-533

6 Sorensen, O, Percy, D, Dales, S In vivo and in vitro models of demyelınatıng disease III JHM virus infection of rats Arch Neurol 1980,37 478-484

7 Sorensen, O, Dugre, R, Percy, D, Dales, S In vivo and in vitro models of demyelınatıng disease caused by mouse hepatitis virus in rats and mice Inf and Immun 1982,37 1248-1260

8 Sorensen, O, Saravanı, A, Dales, S In vivo and in vitro models of demyelınatıng disease XVII The infectious process in athymic rats inoculated with JHM virus Microb Path 1987,2 79-90

9 Zimmer, M J, Dales, S In vivo and in vitro models of demyelınatıng disease XXIV The infectious process in cyclosporin A treated Wistar Lewis rats inoculated with JHM virus Microb Path 1989,6 7-16

10 Sorensen, O, Coulter-Mackıe, M B , Puchalskı, S , Dales, S In vivo and in vitro models of demyelınatıng disease X Progression of JHM virus infection in the central nervous system of the rat during overt and asymptomatic phases Virology 1984,137 347-357

11 Sorensen, O, Beushausen, S, Coulter-Mackıe, M, Adler, R, Dales, S In vivo and in vitro models of demyelınatıng disease In Kurstak, K, Lıpowskı, Z J, Morozow, PV, (eds) Viruses, immunity and mental disorders Plenum Med Book Co 1987 Chapter 18, pp 199-210 
12 Pasıck, J M M, Wilson, G A R, Morrıs, VL, Dales, S SJL/J resistance to mouse hepatitıs virus JHM-induced neurologic disease can be partially overcome by viral variants of $\mathrm{S}$ and host immunosuppression Microb Path 1992,13 1-15

13 Wilson, G A R, Dales, S In vivo and in vitro models of demyelınatıng disease efficiency of virus spread and formation of infectious centers among glial cells is genetically determined by the murine host J Virol $1988,623371-3377$

14 Beushausen, S, Dales, S In vivo and in vitro models of demyelınating disease XI Tropism and differentiation regulate the infectious process of coronavirus in primary explants of the rat CNS Virology 1985,141 89-101

15 Wilson, G A R, Beushausen, S, Dales, S In vivo and in vitro models of demyelinatıng diseases XV Differentiation influences the regulation of coronavirus infection in primary explants of mouse CNS Virology 1986,151 253-264

16 Sorensen, $\mathrm{O}$, Dales, $\mathrm{S}$ In vivo and in vitro models of demyelınatıng disease JHM virus in the rat central nervous system localized by in situ cDNA hybridization and immunofluorescent microscopy J Virol 1985,434-438

17 Pasick, J M M, Dales, S Infection by coronavirus JHM of rat neurons and oligodendrocyte-type-2 astrocyte lineage cells durıng distınct developmental stages J Virol 1991,65 5013-5028

18 Pasick, J M M, Kalıcharran, K, Dales, S Distribution and trafficking of JHM coronavirus structural proteins and virıons in primary neurons and the OBL-21 neuronal cell line J Virol 1994,68 2915-2928

19 Kalıcharran, K, Dales, S a) Dephosphorylation of the nucleocapsid protein of inoculum JHMV may be essential for initiating replication b) Involvement of microtubules and the microtubule-associated protein tau in trafficking of JHM virus and components withın neurons These proceedings, p 57 and p 485

20 Raff, M C , Abney, E R, Miller, R H Two glial cell lineages diverge prenatally in rat optic nerve Dev Biol 1984,106 53-60

21 Beushausen, S , Narındrasorasak, S, Sanwal, B D , Dales, S In vivo and in vitro models of demyelınatıng disease activation of the adenylate cyclase system influences JHM virus expression in explanted rat oligodendrocytes J Virol 1987,61 3795-3803

22 Stohlman, S A, Flemıng, J O, Patton, C D, La1, M M C Synthesis and subcellular localization of the murıne coronavirus nucleocapsid protein Virology 1983,130 527-532

23 Mohandas, D V, Dales, S Endosomal association of a protein phosphatase with high dephosphorylating activity against a coronavirus nucleocapsid protein FEBS Lett 1991,282 419-424

24 Wilson, G A R , Mohandas, D V, Dales, S In vivo and in vitro models of demyelinating disease Possible relationship between induction of regulatory subunit from cAMP dependent protein kinases and inhibition of JHMV replication in cultured oligodendrocytes In Cavanagh, D, Brown, T D K (eds) Coronavirus and their diseases Plenum Press, N Y 